Western North American Naturalist 67(3), (C) 2007, pp. 347-358

\title{
ECOLOGICAL CLASSIFICATION AND MONITORING MODEL FOR THE WYOMING BIG SAGEBRUSH SHRUBSTEPPE HABITAT TYPE OF NORTHEASTERN WYOMING
}

\author{
Lakhdar Benkobi ${ }^{1}$, Daniel W. Uresk² , and R. Dennis Child ${ }^{1}$
}

\begin{abstract}
The purposes of this study were to develop a multivariate statistical model related to plant succession, to classify by seral stage, and to monitor succession in Wyoming big sagebrush shrubsteppe habitat (Artemisia tridentata ssp. wyomingensis / Agropyron smithii-Bouteloua gracilis) in Thunder Basin National Grassland, Wyoming. This model can be used by range and wildlife managers to evaluate management alternatives by assessing changes in plant species cover and composition within and between seral stages. Four ecological seral stages that represent early to late succession were quantitatively identified with an estimated $92 \%$ accuracy. Three key plant species provided the necessary information to define seral stages and monitor trends. Percent canopy cover and percent frequency (used to calculate index values: \% canopy cover $\times \%$ frequency of occurrence) of Wyoming big sagebrush (Artemisia tridentata ssp. wyomingensis), western wheatgrass (Agropyron smithii), and blue grama (Bouteloua gracilis) are the only field measurements required for this model.
\end{abstract}

Key words: modeling, classification, succession, seral stages, habitat, sagebrush, shrubsteppe, monitoring, management, diversity, canopy cover, frequency of occurrence, Artemisia tridentata ssp. wyomingensis, Agropyron smithii, Bouteloua gracilis.

Rangeland ecological status undergoes changes over time, following natural and human-induced disturbances. These changes can be quantified using multivariate statistical models of plant succession (MacCracken et al. 1983, Uresk 1990). Plant succession has been used in classification studies for western forest and rangelands for many years (Sampson 1919, Humphrey 1947, Daubenmire 1952, 1968 , Daubenmire and Daubenmire 1968, Hanson et al. 1984, Dyksterhuis 1985, Hoffman and Alexander 1987, Girard et al. 1989, Westoby et al. 1989). However, subjective interpretations made it difficult to obtain consistent measurements of vegetation trend. With multivariate quantitative models of plant succession, resource managers can easily obtain accurate quantitative measurements to relate to management effects and then evaluate the results, both on a 1-time and on a repeatable basis.

Over the last few decades, rangeland condition classification concepts have provided resource managers with a framework for evaluating vegetation changes in response to natural events (weather, fire) and to management practices (Smith 1988, Holechek et al. 1989, Westoby et al. 1989). Range classification methods used by the Soil Conservation Service (USDA SCS 1976) have not been sensitive enough to detect slow secondary succession in arid rangeland (Tausch et al. 1993, Samuel and Hart 1994). Other multivariate and ordination techniques (Mueller-Dombois and Ellenberg 1974, del Moral 1975, McLendon and Dahl 1983, Foran et al. 1986, Mosely et al. 1986) refined vegetation classification, but did not provide practical tools such as quantitative equations or models so that range managers could quantify successional course. Comprehensive reviews, which present the values and limitations of range condition and trend classification techniques, are provided in a publication of the National Research Council (1994).

State and transition models for plant succession have received much attention in recent years, primarily as an approach for describing ecological processes for plants. These models, as with the current study, are similar and provide discrete categories based upon a few fundamental ecological processes and upon

\footnotetext{
${ }^{1}$ Department of Forest, Rangeland, and Watershed Stewardship, College of Natural Resources, Colorado State University, Fort Collins, CO 80523. SD 57702 .

2Corresponding author. USDA Forest Service, Rocky Mountain Research Station, Forest and Grassland Research Lab, 3221 South Highway 16, Rapid City,
} 
relationships of key indicators for transition or plant succession (Bestelmyer et al. 2003, Stringham et al. 2003).

The research we report here provides a statistical multivariate model that can be used by range managers to determine seral stages within a contemporary habitat type and a method to determine successional trends within and among seral stages. This developed model consists of interrelationships from a set of plant species (variables) that best characterizes the habitat type throughout the course of succession. The objectives were to (1) develop and test an ecological classification and monitoring model for Wyoming big sagebrush (Artemisia tridentata ssp. wyomingensis) shrubsteppe habitat in Thunder Basin National Grassland, (2) define and describe the seral stages, (3) present the model application and management implications, and (4) provide sampling and monitoring protocols.

\section{STUdy AREA}

The study was conducted on Thunder Basin National Grassland (TBNG) in northeastern Wyoming on big sagebrush shrubsteppe habitat (Thilenius et al. 1995). Thunder Basin covers approximately 729,000 ha (1.8 million acres). About 231,750 ha $(572,224$ acres) belong to the National Forest System and are intermingled with Bureau of Land Management, state, and private lands.

\section{Physiography and Geology}

Thunder Basin National Grassland is located in the Powder River Basin, a topographic depression filled with deep sediments and rocks, between the Bighorn Mountains and the Black Hills (Thilenius et al. 1995, von Ahlefeldt et al. 1992). It contains coal beds, shales, and sandstones. Drainages include the Belle Fourche and Cheyenne River systems. Differences in elevation, relief, and landform delineate the grassland into 4 different areas: (1) upland plains, a high rolling plateau on the western edge of the grassland, (2) steep slope escarpments, 328 feet $(100 \mathrm{~m})$ to 394 feet $(120 \mathrm{~m})$ high, known as the Rochelle Hills, located on the western edge of the upland plains, (3) gently sloping plain, broken into knobs and ridges, located east of the Rochelle Hills, and (4) shale uplands, containing bentonite. Elevations range from 3937 feet $(1200 \mathrm{~m})$ at the southeastern corner to a maximum of 5250 feet $(1600 \mathrm{~m})$ at the Rochelle Hills. The maximum elevation at the northern part (Spring Creek) is about 4265 feet $(1300 \mathrm{~m})$.

\section{Climate}

The climate of TBNG is interior continental with hot summers and cold winters. Strong winds, often up to 40 miles per hour (64 kilometers per hour), occur any time of the year. The mean annual precipitation ranges from 12 inches $(30 \mathrm{~cm})$ in central TBNG to 16 inches $(40 \mathrm{~cm})$ in the northern part (Spring Creek). Short-duration intense thunderstorms, sometimes accompanied by damaging hail, occur from May to September. The mean annual temperature ranges from $43^{\circ} \mathrm{F}\left(6^{\circ} \mathrm{C}\right)$ to $47^{\circ} \mathrm{F}$ $\left(8^{\circ} \mathrm{C}\right)$. The maximum temperature ranges from $104^{\circ} \mathrm{F}\left(40^{\circ} \mathrm{C}\right)$ to $110^{\circ} \mathrm{F}\left(44^{\circ} \mathrm{C}\right)$. The minimum temperature ranges from $-36^{\circ} \mathrm{C}$ to $-44^{\circ} \mathrm{C}$. The frost-free period averages 120 days (Martner 1986). Precipitation through the year in relation to temperature is similar for all areas except that, from July to December, precipitation in Dull Center, Upton, and the Rochelle Hills drops sharply compared to precipitation in Gillette. According to von Ahlefeldt et al. (1992), this difference is due to the ability of Gulf moisture to penetrate into the northern Great Plains to produce summer storms. Most of the precipitation in TBNG is in the 30-38-cm (12-15-inch) northern plain precipitation zone (USDA SCS 1999).

\section{Soils}

The surface soils are light colored, and subsoils are light brown or reddish brown (Thilenius et al. 1995). On rolling uplands, the C horizon is approximately $1 \mathrm{~m}$ deep. Steep slopes have only a few centimeters of soil, or soil material overlies bedrock. Rock outcrops are common on the steeper slopes. Soil texture in some areas varies from windblown sand to shale and clay. The bake materials, known as clinker or locally as "scoria," formed in areas where seams of coal burned and baked the nearby sediments to form the natural brown or reddish brown, medium-textured, shallow, gravelly and rocky substrate. Soil parent material is primarily tertiary sandstone and clay shale. A more detailed description is provided by Thilenius et al. (1995). 


\section{Vegetation}

TBNG vegetation consists of 22 major types with associated soils and the general habitat described by Thilenius et al. (1995). These vegetation types provide the framework for this study. Two types, (1) Artemisia tridentata ssp. wyomingensis / Agropyron smithii $(n=4)$ and (2) Artemisia tridentata ssp. wyomingensis / Bouteloua gracilis-Agropyron smithii ( $n=$ $15)$, were combined in our study $(n=121)$ through statistical procedures into 1 type, Artemisia tridentata ssp. wyomingensis / Agropyron smithii-Bouteloua gracilis (Wyoming big sagebrush / western wheatgrass-blue grama), for development of a classification and monitoring system. This type is very common throughout the Thunder Basin grasslands. Small sample sizes for both types could account for the separation into 2 types in the previous study.

\section{Methods}

Data collection and analyses followed Uresk's (1990) procedures. A preliminary ground reconnaissance of the TBNG upland shrubsteppe vegetation type (Artemisia tridentata ssp. wyomingensis / Agropyron smithiiBouteloua gracilis) began in mid-June 1993 to assess vegetation variability on the study area. Sites were selected so that the existing full range of natural variability in the vegetation would be explained by the sampling. All nomenclature follows Great Plains Flora Association (1986).

An additional 5 sites with 5 individuals of Wyoming big sagebrush per site were collected to identify the subspecies of big sagebrush in the study area. Samples were analyzed at the USDA Forest Service, Rocky Mountain Research Station, Shrub Sciences Laboratory, Provo, Utah, by the following methods: chromosome numbers, ultraviolet test, and sagebrush distribution (McArthur and Sanderson 1999).

Data were collected on 121 macroplots (sites). Each macroplot was randomly selected within 1 of 3 perceived seral stages (early, mid-, and late stages). At each macroplot, 2 parallel 99-foot $(30-\mathrm{m})$ transects were set 66 feet $(20 \mathrm{~m})$ apart. At 3.28-foot (1-m) intervals along each transect, we sampled canopy cover, frequency of each plant species, plant litter, and bare ground within each $8 \times 20$-inch $(20 \times$ $50-\mathrm{cm}$ ) microplot (Daubenmire 1959). All macroplot data (60 microplots) for each site were averaged for each plant species and other variables. Average canopy cover (\%) was multiplied by frequency of occurrence $(\%)$ to produce an index value for data analyses (Uresk 1990).

Principal component analysis (Norusis 1992) removed plant species that did not account for much of the variation in the data. Six plant species, namely, Wyoming big sagebrush, western wheatgrass, blue grama, threadleaf sedge (Carex filifolia), prairie junegrass (Koeleria pyramidata), and needle-and-thread (Stipa comata), were retained as major variables for further analyses. Data were then subjected to a nonhierarchical clustering procedure, ISODATA (Ball and Hall 1967, del Morel 1975), which grouped the 121 sites into 4 distinct clusters (seral stages). Then stepwise discriminant analysis (Norusis 1992) selected Wyoming big sagebrush, western wheatgrass, and blue grama as the best variables $(\alpha=0.05)$ to be used in the classification and monitoring model. All variables were entered in the final analyses to check whether the previous selection of the 3 plant species was still consistent. Misclassification error rates were estimated using cross-validation procedures (SAS Institute, Inc. 1988). We field-tested the model by collecting additional data during the 2 nd year (1994). We used a power test to estimate the number of macroplots required to classify and monitor the Wyoming big sagebrush vegetation type (Zar 1984) with an $80 \%$ confidence level.

\section{Results AND Discussion}

Genetic analyses of big sagebrush collected throughout the study area confirmed that Wyoming big sagebrush was the only subspecies present. Growth form varied from short- to tall-statured plants.

\section{Classification Functions}

Four distinct seral stages (early to late), were defined in the TBNG Wyoming big sagebrush shrubsteppe habitat. Stepwise discriminant analysis showed significant differences among these seral stages $(P<0.001)$. Three canonical discriminant functions explained 
TABLE 1. Standardized canonical discriminant function coefficients and percent explained variation for total vegetation.

\begin{tabular}{lccc}
\hline Species & $\begin{array}{c}\text { Function } \\
1\end{array}$ & $\begin{array}{c}\text { Function } \\
2\end{array}$ & $\begin{array}{c}\text { Function } \\
3\end{array}$ \\
\hline Big sagebrush & -0.74 & 0.25 & 0.65 \\
$\quad$ Western wheat- & & & \\
$\quad$ grass & 0.30 & 0.96 & -0.10 \\
Blue grama & 0.55 & 0.01 & 0.85 \\
$\quad \begin{array}{l}\text { Explained } \\
\quad \text { variation }(\%)\end{array}$ & 57.66 & 25.11 & 17.23 \\
\hline
\end{tabular}

nearly $100 \%$ of total variation in the vegetation. The relative importance of each plant species in each canonical function is indicated by the highest standardized coefficient (Table 1). Each variable is heavily weighted at a separate function, which reflects the biotic potential of each key plant species in characterizing vegetation dynamics within the ecological system. Big sagebrush is dominant in function 1 (late seral stage), western wheatgrass in function 2 (late-intermediate), and blue grama in function 3 (early-intermediate). All 3 plant species showed very low index values in the early seral stage (Fig. 1). Many other plant species that were present in this habitat type were not retained as indicators of seral stages, and were dropped from the sequence of statistical procedures because they showed few differences among the seral stages. Wyoming big sagebrush, western wheatgrass, and blue grama were the best indicators of vegetation succession in the TBNG big sagebrush shrubsteppe habitat type.

Classification coefficients were derived from Fisher's model and canonical functions. Fisher's coefficient-based model defines seral stages only (Benkobi and Uresk 1996); however, the calculations are easy and can be done by hand in the field. The canonical coefficient-based model presented in this paper (Table 2) defines seral stages and provides quantitative information about successional trend within seral stages.

Overall application accuracy, obtained from cross-validation procedures (SAS Institute 1988), was $92 \%$. Specific cross-validation results showed classification errors that were likely to occur for each seral stage during applications of this model. These errors were $<1 \%$ for the late seral stage, about $4 \%$ for late-intermediate, $5 \%$ for early-intermediate, and $10 \%$ for early.
TABLE 2. Canonical discriminant function coefficients for classification of seral stages and prediction of successional trends in Thunder Basin National Grassland sagebrush shrubsteppe habitat.

\begin{tabular}{|c|c|c|c|}
\hline & $\begin{array}{c}\text { Function } \\
1\end{array}$ & $\begin{array}{c}\text { Function } \\
2\end{array}$ & $\begin{array}{c}\text { Function } \\
3\end{array}$ \\
\hline \multicolumn{4}{|c|}{ Key plant canonical coefficients } \\
\hline Big sagebrush & -0.000795 & 0.000264 & 0.000694 \\
\hline $\begin{array}{l}\text { Western wheat } \\
\text { grass }\end{array}$ & 0.000761 & 0.002420 & -0.000246 \\
\hline Blue grama & 0.000987 & 0.000024 & 0.001536 \\
\hline Constant & -0.187 & -2.085 & -2.423 \\
\hline \multicolumn{4}{|c|}{ Seral stage mean canonical coefficients } \\
\hline Late & -3.359 & 0.257 & 0.994 \\
\hline $\begin{array}{l}\text { Late-inter- } \\
\text { mediate }\end{array}$ & 0.957 & 2.479 & -0.628 \\
\hline $\begin{array}{l}\text { Early-inter- } \\
\text { mediate }\end{array}$ & 0.073 & -1.018 & -0.899 \\
\hline Early & 2.769 & -0.500 & 1.732 \\
\hline
\end{tabular}

\section{Seral Stages}

Seral stages were distinguished from one another by the distribution and abundance of key plant species characterizing the habitat type (Table 3). Based on the variability of the vegetation present today, 4 distinct seral stages ranging from early to late succession were identified in TBNG Wyoming big sagebrush shrubsteppe habitat (Artemisia tridentata ssp. wyomingensis / Agropyron smithii-Bouteloua gracilis).

LATE.-The late seral stage was dominated by Wyoming big sagebrush, mostly in tall, mature stands. Western wheatgrass and blue grama dominated the understory species with low cover and frequency values (Table 4). Other graminoids were needle-and-thread, a few individuals of prairie junegrass, and threadleaf sedge. Cheatgrass (Bromus tectorum) was very common. Other shrubby plants included fringed sage (Artemisia frigida; Table 4). Plant richness consisted of 38 forbs, 18 graminoids, and 5 shrubs (Fig. 2). Perennial graminoids were nearly always present except in patches where big sagebrush stands were dense enough to shade out the understory vegetation. Twenty-five sites of the 121 used for the cluster and discriminant analyses were assigned to this seral stage.

LaTE-INTERMEDiaTE.-The composition of vegetation in this seral stage was dominated by a mixture of graminoids and shrubs (Table 5). Wyoming big sagebrush still gave character to the landscape over extensive areas of TBNG; 


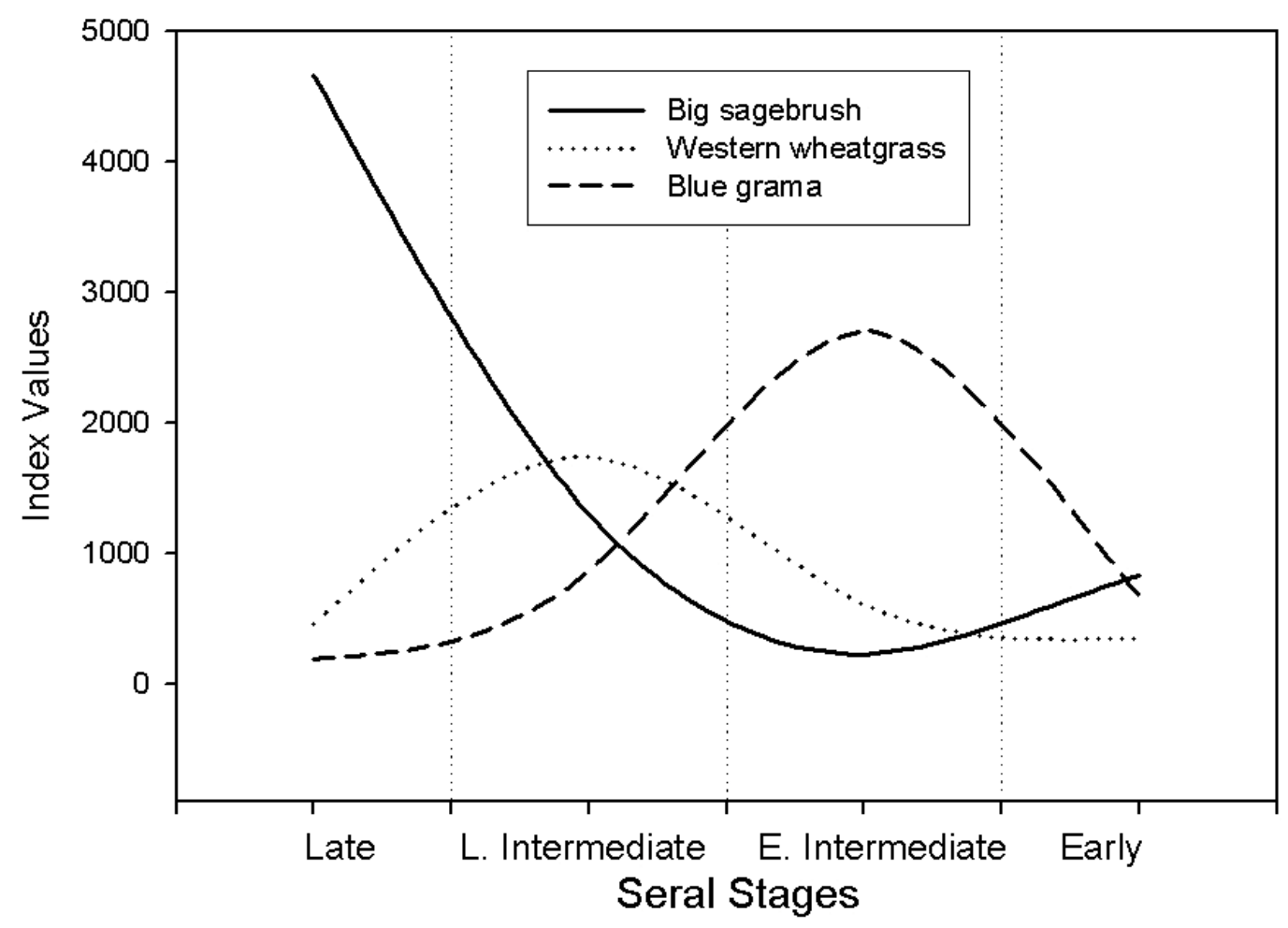

Fig. 1. Index values of vegetation by plant species through 4 seral stages in Thunder Basin National Grassland sagebrush shrubsteppe. Adapted from Benkobi and Uresk (1996).

however, graminoids were more plentiful. Western wheatgrass was the dominant graminoid followed by blue grama (Table 5). Other moderately abundant graminoids were needle-andthread and prairie junegrass. The forb component was dominated by plantain (Plantago spp.) and plains pricklypear (Opuntia polyacantha; Table 5). Plant richness for this stage comprised 45 forbs, 20 graminoids, and 9 shrubs (Fig. 2). Twenty-three sites were clustered into this category.

EarLY-INTERMEDiate.-Shrubs were less abundant in the early-intermediate stage than in the previous seral stage, and graminoids were abundant (Table 6). Wyoming big sagebrush was mostly represented by widely spaced stands. Blue grama was the dominant key plant species (Table 6). Needle-and-thread and threadleaf sedge were codominant graminoids. Plains pricklypear and plantain were the dominant forbs (Table 6). Plant richness in this seral stage was represented by 48 forbs, 17 graminoids, and 7 shrubs (Fig. 2). This seral stage was represented by 21 sites.
EARLY.-At this seral stage, big sagebrush was widely distributed and more abundant than in the previous seral stage. Graminoids were present but patchy. Plains pricklypear was less common than in the other 3 seral stages. Plantain species were common (Table 7). Plant richness was represented by 74 forbs, 30 graminoids, and 11 shrubs (Fig. 2). The number of herbaceous and shrub species was greatest compared with the other 3 seral stages. A total of 52 sites were clustered in this seral stage.

\section{ECOlogical Considerations}

The ability to identify seral stages and relate them to prescribed management activities is essential for range managers to achieve a desired condition (Dyksterhuis 1985, Uresk 1990). Determination of seral stages can be achieved using the developed multivariate classification and monitoring model, which is based on ecological concepts of plant succession (Clements 1916, Dyksterhuis 1949, Daubenmire 1968). 
TABLE 3. Mean index, mean canopy cover, and mean frequency of occurrence for the key plants used to monitor and predict the defined seral stages in Thunder Basin National Grassland sagebrush shrubsteppe. Standard errors are given in parentheses.

\begin{tabular}{|c|c|c|c|c|}
\hline Seral stages & $n$ & Big sagebrush & Western wheatgrass & Blue grama \\
\hline \multicolumn{5}{|l|}{ Index values ${ }^{\mathrm{a}}$} \\
\hline Late & 25 & $4666(248)$ & $458(84)$ & $191(33)$ \\
\hline Late-intermediate & 23 & $1297(246)$ & $1738(100)$ & $863(139)$ \\
\hline Early-intermediate & 21 & $222(30)$ & $605(70)$ & $2707(120)$ \\
\hline Early & 52 & $835(174)$ & $343(58)$ & $671(108)$ \\
\hline \multicolumn{5}{|l|}{ Canopy cover $(\%)$} \\
\hline Late & 25 & $55(2.1)$ & $8(1.2)$ & $6(0.8)$ \\
\hline Late-intermediate & 23 & $22(3.1)$ & $20(1.0)$ & $14(1.7)$ \\
\hline Early-intermediate & 21 & $7(0.9)$ & $8(1.3)$ & $30(1.8)$ \\
\hline Early & 52 & $17(1.6)$ & $7(0.6)$ & $12(0.9)$ \\
\hline \multicolumn{5}{|c|}{ Frequency of occurrence (\%) } \\
\hline Late & 25 & $85(1.6)$ & $60(4.9)$ & $32(2.3)$ \\
\hline Late-intermediate & 23 & $60(4.8)$ & $85(1.7)$ & $61(4.7)$ \\
\hline Early-intermediate & 21 & $27(2.8)$ & $63(5.9)$ & $87(2.6)$ \\
\hline Early & 52 & $51(2.8)$ & $50(2.6)$ & $57(2.7)$ \\
\hline
\end{tabular}

${ }^{\text {Index value }}=$ canopy cover $(\%) \times$ frequency of occurrence $(\%)$.

However, plant succession in this study is not employed as defined in procedures of the USDA SCS (1976). Those procedures use percent of climax to determine current range condition. Our model obtains successional status by using multivariate quantitative equations developed with data from a contemporary habitat type. These equations consist of interrelationships of data from a set of plant species that occur throughout the defined seral stages (early to late). Thus, the developed model determines seral stages regardless of hypothetical past or future climax vegetation. It is difficult to predict long-term ( $\geq 100$ years) past or future climax condition; at best, such a prediction becomes an ecological guess.

Knowledge of hypothetical climax vegetation is not required when managers apply the developed model to determine seral stages because (1) vegetation data that served to develop the model were collected over a range of natural variation from early to late plant succession on a habitat type that is present today and (2) every sampled plant species was included as a variable, as well as vegetation litter and bare ground, in a sequence of multivariate statistical analyses to determine the set of variables that best characterized the seral stages of the habitat type. The selection of key plant species was entirely quantitative, and was thus free of subjective input. For grazing management purposes, it is more realistic to monitor habitat types based on key plant spe- cies present today than it is to guess a hypothetical past or future climax vegetation.

\section{MANAGEMENT IMPLiCATIONS}

Managers concerned with biological diversity face a trade-off situation when prescribing management practices for the vegetation type Artemisia tridentata ssp. wyomingensis / Agropyron smithii-Bouteloua gracilis. The 4 seral stages can be defined as management alternatives. No individual seral stage is suitable for multiple-use management. The entire seral range (from early to late) is necessary to accommodate plant species diversity, wildlife habitat, livestock production, and recreation (Bowns and Bagley 1986, Uresk 1990, Samuel and Hart 1994). In this vegetation type, the intermediate stages of succession are superior to the late seral stage for livestock production because of the greater availability of forage species.

Plant species richness is greater in the early seral stage than in the other 3 seral stages. Samuel and Hart (1994), who conducted a biological survey in northeastern Wyoming, reported that biological diversity was higher in early seral stage sites that were not dominated by blue grama. Livestock grazing can be used as a periodic disturbance to generate sites in early seral condition. However, additional management factors such as soil erosion must also be considered (Benkobi and Uresk 1996). 
TABLE 4. Late seral stage; average canopy cover and frequency of occurrence with corresponding standard errors $(n=25)$ for the dominant plant species.

\begin{tabular}{lccccc}
\hline & \multicolumn{2}{c}{ Canopy cover $(\%)$} & & \multicolumn{2}{c}{ Frequency of occurrence $(\%)$} \\
\cline { 2 - 3 } \cline { 5 - 6 } Plant species & Mean & $s_{\bar{x}}$ & & Mean & $s_{\bar{x}}$ \\
\hline Artemisia tridentata ssp. wyomingensis & 55.06 & 2.05 & 84.7 & 1.62 \\
Stipa comata & 7.97 & 1.54 & 60.16 & 4.93 \\
Agropyron smithii & 7.62 & 1.15 & 28.87 & 4.17 \\
Bromus tectorum & 6.89 & 2.37 & 27.17 & 4.35 \\
Bouteloua gracilis & 6.00 & 0.77 & 31.86 & 2.28 \\
Opuntia polyacantha & 4.81 & 1.02 & 18.99 & 3.44 \\
Koeleria pyramidata & 2.74 & 0.81 & 13.84 & 3.88 \\
Vulpia octoflora & 2.25 & 0.62 & 16.45 & 3.81 \\
Carex filifolia & 1.79 & 0.54 & 8.67 & 2.10 \\
Artemisia frigida & 0.84 & 0.33 & 5.51 & 1.91 \\
Shrubs & 60.76 & 2.24 & 83.70 & 1.83 \\
Graminoids & 34.42 & 2.92 & 87.83 & 2.26 \\
Forbs & 8.14 & 1.05 & 53.04 & 4.05 \\
Litter & 13.77 & 2.14 & 43.41 & 4.18 \\
Bare soil & 8.78 & 1.12 & 42.54 & 4.27 \\
\hline
\end{tabular}

TABLE 5. Late-intermediate seral stage; average canopy cover and frequency of occurrence with corresponding standard errors $(n=23)$ for the dominant plant species.

\begin{tabular}{|c|c|c|c|c|}
\hline \multirow[b]{2}{*}{ Plant species } & \multicolumn{2}{|c|}{ Canopy cover $(\%)$} & \multicolumn{2}{|c|}{ Frequency of occurrence $(\%)$} \\
\hline & Mean & $s_{\bar{x}}$ & Mean & $s_{\bar{x}}$ \\
\hline Artemisia tridentata ssp. wyomingensis & 21.80 & 3.07 & 59.50 & 4.75 \\
\hline Agropyron smithii & 20.31 & 0.99 & 85.21 & 1.65 \\
\hline Bouteloua gracilis & 14.14 & 1.74 & 61.09 & 4.72 \\
\hline Stipa comata & 7.94 & 1.59 & 28.04 & 4.09 \\
\hline Opuntia polyacantha & 7.63 & 1.52 & 24.47 & 4.50 \\
\hline Koeleria pyramidata & 5.68 & 1.25 & 29.13 & 5.34 \\
\hline Plantago spp. & 4.80 & 0.99 & 39.09 & 6.96 \\
\hline Carex filifolia & 3.79 & 1.68 & 12.65 & 4.59 \\
\hline Plantago patagonica & 2.31 & 1.79 & 11.21 & 5.22 \\
\hline Bromus tectorum & 2.19 & 0.94 & 13.26 & 3.54 \\
\hline Vulpia octoflora & 0.98 & 0.32 & 10.83 & 3.11 \\
\hline Bromus japonicus & 0.81 & 0.41 & 6.06 & 2.14 \\
\hline Graminoids & 51.42 & 2.85 & 98.22 & 0.61 \\
\hline Shrubs & 21.84 & 3.16 & 46.29 & 4.85 \\
\hline Forbs & 17.92 & 1.98 & 78.26 & 3.78 \\
\hline Litter & 8.81 & 1.48 & 39.39 & 4.63 \\
\hline Bare soil & 15.81 & 2.30 & 70.23 & 4.78 \\
\hline
\end{tabular}

The late-intermediate and the early-intermediate seral stages of this habitat type are dominated by western wheatgrass and blue grama, respectively (Table 3 ). The former is a palatable perennial grass, which is good forage and a decreaser when subjected to overgrazing (Lang 1973, Johnson 1979, Müeggler and Stewart 1980). The latter is a palatable perennial grass and is also good forage, but it is considered an increaser and withstands grazing pressure better than western wheatgrass. Other palatable graminoids-needle-and-thread, prairie junegrass, and threadleaf sedge-contribute substantially to forage production and are considered decreasers. Big sagebrush is considered the principal increaser in this habitat type (Weaver and Albertson 1956, Lang 1973, Johnson 1979, Holechek and Stephenson 1983).

Grazing has severely affected the grassland physiognomy on some areas of TBNG in the past (Paris and Paris 1974); that is, midgrass prairie has been replaced with shortgrass 


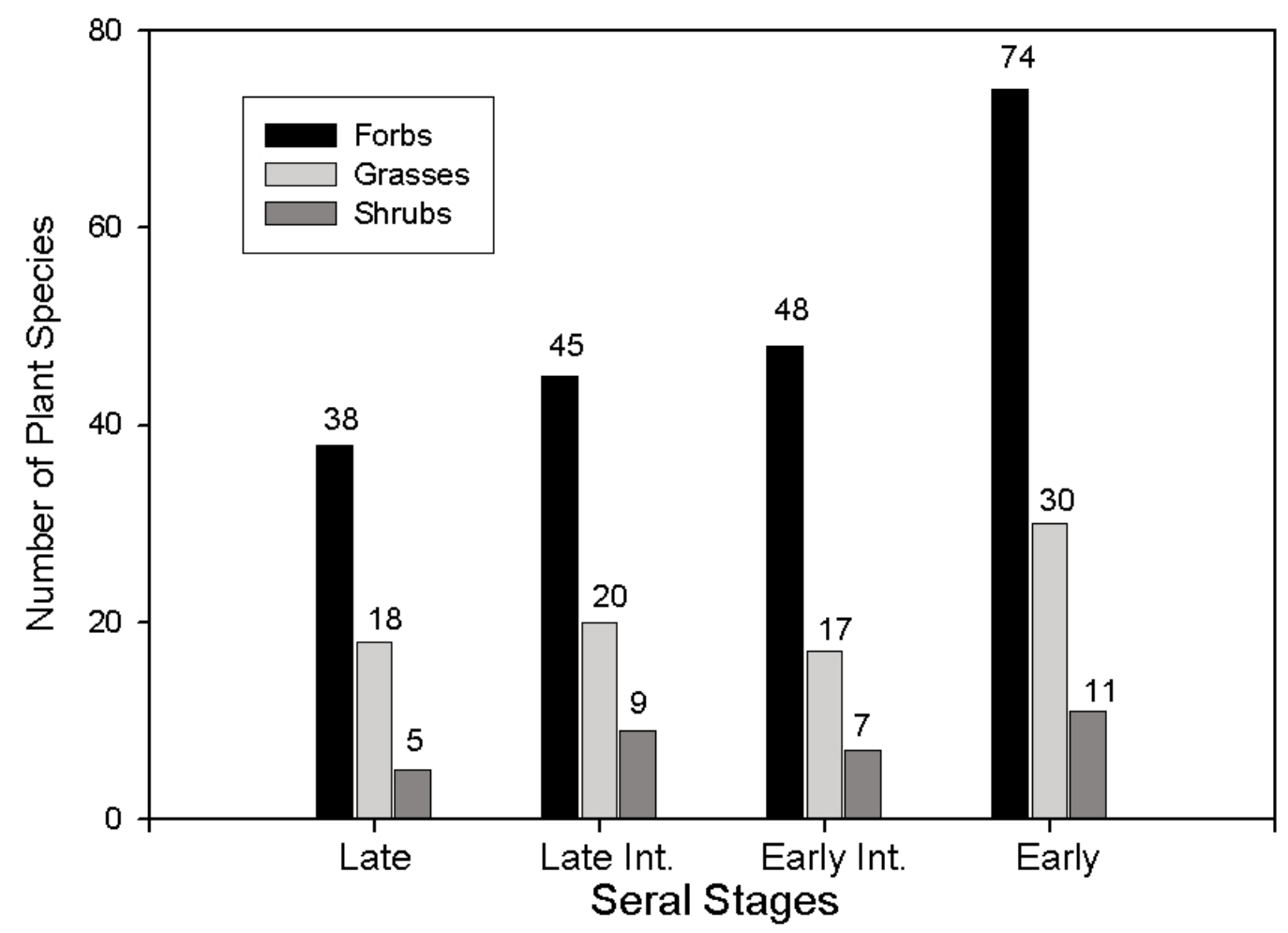

Fig. 2. Diversity of vegetation by plant category though 4 seral stages in Thunder Basin National Grassland sagebrush shrubsteppe.

prairie. These grazed areas have greater amounts of blue grama, at the expense of midgrasses, than range sites that are not subjected to heavy grazing. Our data show 73 sites over a total of 121 sites (early-intermediate and early seral stages combined) where blue grama is the dominant graminoid.

Where disturbance to the soil is not severe and not continuous, the return time of palatable perennial grasses, through secondary succession, has been estimated to be 50 years (Costello 1944) and 61 years (Samuel and Hart 1994). Ries et al. (1979) reported that in a plowed native range in TBNG, secondary succession took 40 years to reestablish the native vegetation to nearly the same or better condition compared to undisturbed fields. Wyoming big sagebrush took an average of about 20 years to reestablish after major disturbances by fire, chemical, and mechanical treatments in southwestern Montana (Watts and Wambolt 1996). The developed classification and monitoring model can be used to quantify the rela- tionship between various grazing intensities and plant succession to determine the grazing levels necessary to maintain or restore the desired successional status of the vegetation. In addition, useful information about wildlife activities and their relationships to seral stages in plant communities can be obtained to determine wildlife habitat needs for inclusion in a management plan (Uresk 1990, Rumble and Gobeille 1995).

\section{ApPlication AND Monitoring}

Although sagebrush steppe is common on western rangelands, the application of this model is limited to its specific habitat type (Artemisia tridentata ssp. wyomingensis / Agropyron smithii-Bouteloua gracilis; Beetle and Johnson 1982, Thilenius et al. 1995). Küchler (1964) limited this habitat type to southeastern Montana and Wyoming, but Bailey (1980) limited it to the Wyoming Basin Province only. However, Johnson (1979) stated that the northeastern Wyoming big sagebrush steppe was 
TABLE 6. Early-intermediate seral stage; average canopy cover and frequency of occurrence with corresponding standard errors $(n=21)$ for the dominant plant species.

\begin{tabular}{|c|c|c|c|c|}
\hline \multirow[b]{2}{*}{ Plant species } & \multicolumn{2}{|c|}{ Canopy cover $(\%)$} & \multicolumn{2}{|c|}{ Frequency of occurrence (\%) } \\
\hline & Mean & $s_{\bar{x}}$ & Mean & $s_{\bar{x}}$ \\
\hline Bouteloua gracilis & 30.22 & 1.80 & 86.76 & 2.57 \\
\hline Stipa comata & 12.02 & 2.01 & 45.56 & 5.50 \\
\hline Carex filifolia & 9.42 & 2.38 & 33.09 & 6.41 \\
\hline Agropyron smithii & 8.24 & 1.30 & 62.52 & 5.94 \\
\hline Artemisia tridentata ssp wyomingensis & 7.38 & 0.96 & 27.29 & 2.75 \\
\hline Opuntia polyacantha & 6.35 & 1.61 & 22.08 & 4.30 \\
\hline Plantago patagonica & 2.84 & 1.15 & 23.33 & 7.07 \\
\hline Plantago spp. & 2.39 & 0.74 & 23.43 & 4.81 \\
\hline Aristida longifolia & 1.54 & 0.54 & 6.02 & 2.12 \\
\hline Phlox hoodii & 1.36 & 0.70 & 12.18 & 4.42 \\
\hline Koeleria pyramidata & 1.22 & 0.35 & 10.23 & 2.47 \\
\hline Artemisia frigida & 0.90 & 0.41 & 6.57 & 2.76 \\
\hline Graminoids & 57.71 & 2.47 & 97.82 & 0.96 \\
\hline Forbs & 15.93 & 1.84 & 76.30 & 3.34 \\
\hline Shrubs & 7.31 & 1.10 & 22.04 & 3.05 \\
\hline Litter & 6.31 & 1.06 & 38.29 & 5.79 \\
\hline Bare soil & 20.21 & 2.34 & 87.92 & 2.13 \\
\hline
\end{tabular}

TABLE 7. Early seral stage; average canopy cover and frequency of occurrence with corresponding standard errors $(n=52)$ for the dominant plant species.

\begin{tabular}{|c|c|c|c|c|}
\hline \multirow[b]{2}{*}{ Plant species } & \multicolumn{2}{|c|}{ Canopy cover $(\%)$} & \multicolumn{2}{|c|}{ Frequency of occurrence (\%) } \\
\hline & Mean & $s_{\bar{x}}$ & Mean & $s_{\bar{x}}$ \\
\hline Artemisia tridentata ssp. wyomingensis & 16.51 & 1.57 & 50.59 & 2.78 \\
\hline Bouteloua gracilis & 11.83 & 0.85 & 56.76 & 2.72 \\
\hline Stipa comata & 11.25 & 1.08 & 45.96 & 3.46 \\
\hline Carex filifolia & 8.00 & 1.23 & 28.83 & 3.95 \\
\hline Agropyron smithii & 6.82 & 0.57 & 50.39 & 2.64 \\
\hline Koeleria pyramidata & 4.75 & 0.75 & 25.90 & 3.14 \\
\hline Opuntia polyacantha & 3.51 & 0.69 & 15.26 & 2.55 \\
\hline Stipa viridula & 2.12 & 0.83 & 7.26 & 2.67 \\
\hline Artemisia frigida & 1.54 & 0.30 & 10.21 & 1.70 \\
\hline Plantago spp. & 1.47 & 0.61 & 11.39 & 2.71 \\
\hline Bromus tectorum & 1.32 & 0.32 & 10.26 & 1.72 \\
\hline Aristida longifolia & 1.07 & 0.32 & 5.14 & 1.38 \\
\hline Graminoids & 47.78 & 1.87 & 93.73 & 2.54 \\
\hline Shrubs & 17.07 & 1.69 & 41.72 & 2.88 \\
\hline Forbs & 13.63 & 1.17 & 71.86 & 3.02 \\
\hline Litter & 11.24 & 1.41 & 50.40 & 3.90 \\
\hline Bare soil & 14.63 & 1.57 & 73.07 & 3.44 \\
\hline
\end{tabular}

consistent with a mixed-grass prairie elsewhere, except for the greater dominance of sagebrush in the shrubsteppe.

When applying this classification model outside the area, the user must ensure that big sagebrush is the dominant shrub and that blue grama and western wheatgrass are the dominant graminoids (Table 3). Other codominant graminoids include needle-and-thread, threadleaf sedge, and prairie junegrass. This classification system cannot be applied to the Wyoming big sagebrush type that occurs on very shallow soils associated with relatively narrow ridgetops in TBNG. Understory plant species were much different on narrow ridgetops than species found in the bottomlands. 
Field Measurements and

Assignment of Seral Stages

Application of the model requires a minimum of 2 macroplots per section (640 acres or $259 \mathrm{ha})$ for rangeland seral classification and monitoring. Canopy cover and frequency of occurrence for the 3 key plants (Wyoming big sagebrush, western wheatgrass, and blue grama) are the only required field measurements. During years with above-average precipitation, mid-June-September is a good period for field measurements. Otherwise, the field measurement period could be shorter (early June-midAugust) because identification of plant species becomes more difficult later in the season. All key plants to be measured should exhibit nearly their full expression of growth. Monitoring the trend, based on changes, requires repeated measurements over time on permanent macroplots to estimate changes in the key variables and in the resulting seral stage assignment.

Measurements for canopy cover and frequency of occurrence should be completed as follows: (1) Establish a $66 \times 99$-foot $(20 \times 30$ m) rectangular macroplot within a big sagebrush shrubsteppe habitat. Use the longer sides as transects. (2) Record canopy cover for the 3 key plants (Wyoming big sagebrush, western wheatgrass, blue grama) within $8 \times 20$-inch $(20 \times 50-\mathrm{cm})$ quadrats at 3.3 -foot $(1-\mathrm{m})$ intervals along each transect for a total of 30 quadrats per transect with 60 quadrats per site using Daubenmire's (1959) 6 canopy cover classes. (3) Convert canopy cover classes to percent canopy cover (Daubenmire 1959). Calculate the sum of canopy cover for each plant or variable, and then calculate the macroplot average by dividing the sum by 60 . Count the number of occurrences for each plant, divide by 60 , and multiply by 100 to obtain the percent frequency of occurrence. For each key plant, multiply the average percent canopy cover by the percent frequency of occurrence to obtain the set of key plant index values. (4) Hand-calculate assignment of a seral stage using the Fisher's discriminant coefficients and index values as presented in Benkobi and Uresk (1996).

Alternatively, information on field application, including the programs and workbook for PCs and PDAs, may be obtained on the USDA Forest Service Rangelands web site (Available from: http://www.fs.fed.us/rangelands/ecology/ ecologicalclassification/).
The stage can be assigned by using the Microsoft ${ }^{\circledR}$ Excel workbook BigSagebrush.xls, which we developed using the canonical model presented in this paper. Output consists of probabilities for early, early-intermediate, lateintermediate, and late seral stages, and an assignment of the site sampled to the stage with the highest probability. The workbook is designed to be used in the field on a PDA and accepts raw data (Daubenmire 1959) as input.

Unavoidably, incorrect classifications may occur during application of this classification technique. Less than $1 \%$ of macroplots are likely to be misclassified where vegetation is at a late seral stage, $5 \%$ misclassification can occur where vegetation is at intermediate seral stages, and $10 \%$ misclassification is possible where vegetation is at an early seral stage. When the user questions the classification of a macroplot, care should be taken to ensure that the macroplot being sampled is within the habitat type described in this study. If the user is still in doubt, we recommend sampling another plot location.

\section{Conclusions}

We developed a classification and monitoring system based on plant succession for the TBNG Wyoming big sagebrush shrubsteppe habitat. This classification system uses multivariate statistical methods to determine the key plant species that best predict seral stages within this habitat type. Big sagebrush, western wheatgrass, and blue grama are the 3 key plant species that predict succession or retrogression. The model quantitatively identifies 4 seral stages (early to late) with $92 \%$ accuracy. Classification and monitoring require measurements of canopy cover and frequency of occurrence for the 3 key plant species from 2 different macroplots per section. The model developed is not linear; that is, plant succession does not necessarily move in a linear fashion through all seral stages. For example, disturbance can move an ecological site directly from late to early successional status. Key variables-Wyoming big sagebrush, western wheatgrass, and blue grama-act collectively in the model to determine seral stage assignment and monitoring for trends. The assigned seral stages provide resource managers with 4 options to evaluate management alternatives and outcomes. 


\section{ACKNOWLEDGMENTS}

We thank Rudy King for statistical support and Jody Javersak for manuscript review and editing. Special thanks are given to E. Durant McArthur for subspecies determinations of sagebrush samples collected in Thunder Basin, Wyoming. Tom Juntti was instrumental in writing Excel macros for PCs and PDAs. We also extend thanks to Ryan Tompkins and Robin Cochran for data collection and to Barry Lilly for the web site. Partial financial support was provided by the Medicine Bow National Forest, Thunder Basin National Grassland, and we are indebted to George Wiggins for his knowledge of the grasslands and support for the project. This study was done in cooperation with Colorado State University, Department of Rangeland Ecosystem Science (28CR3-752 and 03-JV-1221609-272), with special thanks to Dr. Harold Goetz.

\section{Literature Cited}

BAILEY, R.G. 1980. Description of the ecoregions of the United States. USDA Forest Service Miscellaneous Publication No. 1391. 77 pp.

BaLl, G.H., AND D.J. HaLl. 1967. A clustering technique for summarizing multivariate data. Behavioral Science 12:153-155.

Beetle, A.A., AND K.L. Johnson. 1982. Sagebrush in Wyoming. Agricultural Experiment Station, University of Wyoming, Laramie. 68 pp.

Benkobi, L., And D.W. Uresk. 1996. Seral stage classification and monitoring model for big sagebrush/western wheatgrass/blue grama. In: J.R. Barrow, E.D. McArthur, R.E. Sosebe, and R.J. Tausch, editors, Shrubland ecosystem dynamics in a changing environment; Proceedings of the symposium; 1995 May 23-25; Las Cruces, NM. General Technical Report INT-338, USDA Forest Service, Intermountain Research Station, Ogden, UT.

Bestelmyer, B.T., J.R. Brown, K.M. Havstad, R. Alexander, G. Chavez, and J.E. Herrick. 2003. Development and use of state-and-transition models for rangelands. Journal of Range Management 56:114126.

Bowns, J.E., AND C.F. BAGLEy. 1986. Vegetation response to long-term sheep grazing on mountain ranges. Journal of Range Management 39:431-434.

CostelLo, D.F. 1944. Natural revegetation of abandoned plowed land in the mixed prairie association of northeastern Colorado. Ecology 25:312-326.

Clements, F.E. 1916. Plant succession: an analysis of the development of vegetation. Washington: Carnegie Institute Publication 242:1-512.

DaubenmiRe, R. 1952. Forest vegetation of northern Idaho and adjacent Washington, and its bearing on concepts of vegetation classification. Ecological Monographs 22:301-306.

1959. A canopy-coverage method of vegetational analysis. Northwest Science 33:43-64.
1968. Plant communities: a textbook of plant synecology. Harper \& Row, New York. 300 pp.

Daubenmire, R., and J.B. Daubenmire. 1968. Forest vegetation of eastern Washington and northern Idaho. Agricultural Experiment Station Technical Bulletin 60, Washington State University, Pullman.

del Moral, R. 1975. Vegetation clustering by means of ISODATA: revision by multiple discriminant analysis. Vegetation 29:179-190.

Dyksterhuis, E.J. 1949. Condition and management of range land based on quantitative ecology. Journal of Range Management 2:104-115.

1985. Follow-up on range sites and condition classes as based on quantitative ecology. Rangelands 7:172-173.

Foran, B.D., G. Bastin, K.A. Shaw. 1986. Range assessment and monitoring in arid lands: the use of classification and ordination in range survey. Journal of Environmental Management 22:67-84.

Girard, M.M., H. GoEtZ, AND A.J. BJugstad. 1989. Native woodland habitat types of southwestern North Dakota. Research Paper RM-281, USDA Forest Service, Rocky Mountain Forest and Range Experiment Station, Fort Collins, CO. 37 pp.

Great Plains Flora Association. 1986. Flora of the Great Plains. University Press of Kansas, Lawrence. $1392 \mathrm{pp}$.

Hanson, P.L., G.R. Hoffman, and A.J. Bjugstad. 1984. The vegetation of Theodore Roosevelt National Park, North Dakota: a habitat type classification. General Technical Report RM-113, USDA Forest Service, Rocky Mountain Forest and Range Experiment Station, Fort Collins, CO. 35 pp.

Hoffman, G.R., AND R.R. AleXander. 1987. Forest vegetation of the Black Hills National Forest of South Dakota and Wyoming: a habitat type classification. Research Paper RM-276. USDA Forest Service, Rocky Mountain Forest and Range Experiment Station, Fort Collins, CO. 48 pp.

Holechek, J.L., R.D. Pieper, and C.H. Herbel. 1989. Range management principles and practices. Prentice-Hall, Inc., Englewood Cliffs, NJ. 501 pp.

HolecheK, J.L., AND T. Stephenson. 1983. Comparison of big sagebrush vegetation in northcentral New Mexico under moderately grazed and grazing excluded conditions. Journal of Range Management 36:455456.

Humphrey, R.R. 1947. Range forage evaluation by the range condition method. Journal of Forestry 45:10-14.

Johnson, K.L. 1979. Basic synecological relationships of the sagebrush types on the high plains of Montana, Wyoming, and the Dakotas. In: G.F. Gifford, F.E. Busby, and J.K. Shaw, editors, The sagebrush ecosystem; a symposium; 1978 April. Utah State University, Logan. $251 \mathrm{pp}$.

KÜChlER, A.W. 1964. Potential natural vegetation of the conterminous United States. American Geographical Society Special Publication No. 36. 116 pp.

LANG, R. 1973. Vegetation changes between 1943 and 1965 on the short grass plains of Wyoming. Journal of Range Management 26:407-409.

MacCracken, J.G., D.W. Uresk., and R.M. Hanson. 1983. Plant community variability on a small area in southeastern Montana. Great Basin Naturalist 43:660-668.

Martner, B.E. 1986. Wyoming climate atlas. University of Nebraska Press, Lincoln. 
McArthur, E.D., and S.C. Sanderson. 1999. Cytogeography and chromosome evolution of subgenus Tridentatae of Artemisia (Asteraceae). American Journal of Botany 86:1754-1775. Available from: http://www .amjbot.org/cgi/content/full/86/12/1754

McLendon, T., AND B.E. DAHL. 1983. A method for mapping vegetation utilizing multivariate statistical techniques. Journal of Range Management 36:457-462.

Mosley, J.C., S.C. Bunting, M. Hironaka. 1986. Determining range condition from frequency data in mountain meadows of central Idaho. Journal of Range Management 39:561-565.

Müeggler, W.F., And W.L. Stewart. 1980. Grassland and shrubland habitat types of western Montana. General Technical Report INT-66, USDA Forest Service, Intermountain Forest and Range Experiment Station, Ogden, UT. 154 pp.

Mueller-Dombois, D., AND H. Ellenberg. 1974. Aims and methods of vegetation ecology. John Wiley \& Sons, Inc., New York. 547 pp.

National Research Council. 1994. Rangeland health: new methods to classify, inventory, and monitor rangelands. National Academy Press, Washington, DC. $180 \mathrm{pp}$.

Norusis, M.J. 1992. SPSS/PC+ professional statistics, version 5.0. SPSS, Inc., Chicago, IL.

Paris, D.H., AND M.J.W. PARIS. 1974. Initial composite report on the environmental impact assessment of the proposed Black Thunder Mine. Volume 1: Black Thunder Project. University of Wyoming, Laramie. 540 pp.

Ries, R.E., H.G. Fisser, and A.T. Harrison. 1979. Vegetation. Pages 2-85 in G.F. Gifford, F.E. Busby, and J.K. Shaw, editors, The sagebrush ecosystem; a symposium; 1978 April. Utah State University, Logan. $251 \mathrm{pp}$.

Rumble, M.A., and J.E. Gobeille. 1995. Wildlife associations in Rocky Mountain juniper in the Northern Great Plains, South Dakota. Pages 80-90 in D.W. Shaw, E.F. Aldon, and C. LoSapio, editors, Desired future conditions for piñon-juniper ecosystems; proceedings of the symposium; 1994 August 8-12; Flagstaff, AZ. General Technical Report RM-258, USDA Forest Service, Rocky Mountain Forest and Range Experiment Station, Fort Collins, CO.

SAMPSON, A.W. 1919. Plant succession in relation to range management. U.S. Department of Agriculture Bulletin No. 791.76 pp.

Samuel, M.J., AND R.H. HaRT. 1994. Sixty-one years of secondary succession on rangelands of the Wyoming High Plains. Journal of Range Management 47:184191.
SAS Institute, InC. 1988. SAS/STAT user's guide, version 6.04. SAS Institute, Inc., Cary, NC. 1028 pp.

Smith, E.L. 1988. Successional concepts in relation to range condition assessment. In: P.T. Tueller, editor, Vegetation science application for rangeland analysis and management. Kluwer Academic Publishers, Boston, MA.

Stringham, T.K., W.C. Krueger, and P.L. Shaver. 2003. State and transition modeling: an ecological process approach. Journal of Range Management 56:106-113.

Tausch, R.J., P.E. Wigrant, And J.W. Burkhard. 1993. Viewpoint: plant community thresholds, multiple steady states, and multiple successional pathways: legacy of the Quaternary? Journal of Range Management 46:439-447.

Thilenius, J.F., G.R. Brown, A.L. Medina. 1995. Vegetation on semi-arid rangeland, Cheyenne River Basin, WY. General Technical Report RM-263, USDA Forest Service, Rocky Mountain Forest and Range Experiment Station, Fort Collins, CO. $60 \mathrm{pp}$.

[USDA NRCS] U.S. Department of Agriculture, Natural Resources Conservation Service. 1999. Wyoming precipitation data [cited on 19 June 2007]. Available from: http://www.ncgc.nrcs.usda.gov/products/ datasets/climate/data/precipitation-state/wy.html

[USDA SCS] U.S. Department of Agriculture, Soil Conservation SERvice. 1976. National range handbook. NRH-1. Washington, DC.

URESK, D.W. 1990. Using multivariate techniques to quantitatively estimate ecological stages in a mixed-grass prairie. Journal of Range Management 43:282-285.

von Ahlefeldt, J., T. Byer, M.R. Edwards, and C. Speas. 1992. Biological diversity technical report for oil and gas leasing EIS-TBNG. USDA Forest Service, Medicine Bow National Forest, Laramie, WY. 177 pp.

WatTs, M.J., AND C.L. Wambolt. 1996. Long-term recovery of Wyoming big sagebrush after four treatments. Journal of Environmental Management 46:95-102.

Weaver, J.E., And F.W. Albertson. 1956. Grasslands of the Great Plains: their nature and use. Johnson Publishing Company, Lincoln, NE. 395 pp.

Westoby, M., B. Walker, I. Noy-Meir. 1989. Opportunistic management for rangelands not at equilibrium. Journal of Range Management 42:266-274.

ZAR, J.H. 1984. Biostatistical analyses. Prentice-Hall, Englewood Cliffs, NJ. 718 pp.

Received 11 November 2005 Accepted 7 November 2006 